\title{
Meaning making in the cosmopolitics of heritage
}

\author{
Christine Tarbett-Buckley \\ College of Indigenous Futures, Arts and Society, Charles Darwin University \\ christine.tarbett-buckley@cdu.edu.au
}

Keywords: Cultural heritage; Northern Territory; heritage narratives; Kakadu National Park

\section{Abstract}

The cosmopolitics of heritage refers to the politics of working cosmologies together and separately simultaneously, in making meaningful stories of the multiple and complex histories that contribute to any place's heritage. In this paper, I recount a visit to a World Heritage site in the Northern Territory of Australia. My story describes a seemingly modest disconcertment about the on-site presentation of the place. Taking this disconcertment seriously I point to some compromises that have been made in waging the cosmopolitics of designing the presentation. My aim in articulating this is to suggest that there are better and worse ways of making these compromises and that careful explicitness, even if the story of place becomes complex and complicated, is a helpful step towards achieving this.

Figure 1: Kakadu National Park, stairway ascending to Angbangbang Rock Shelter

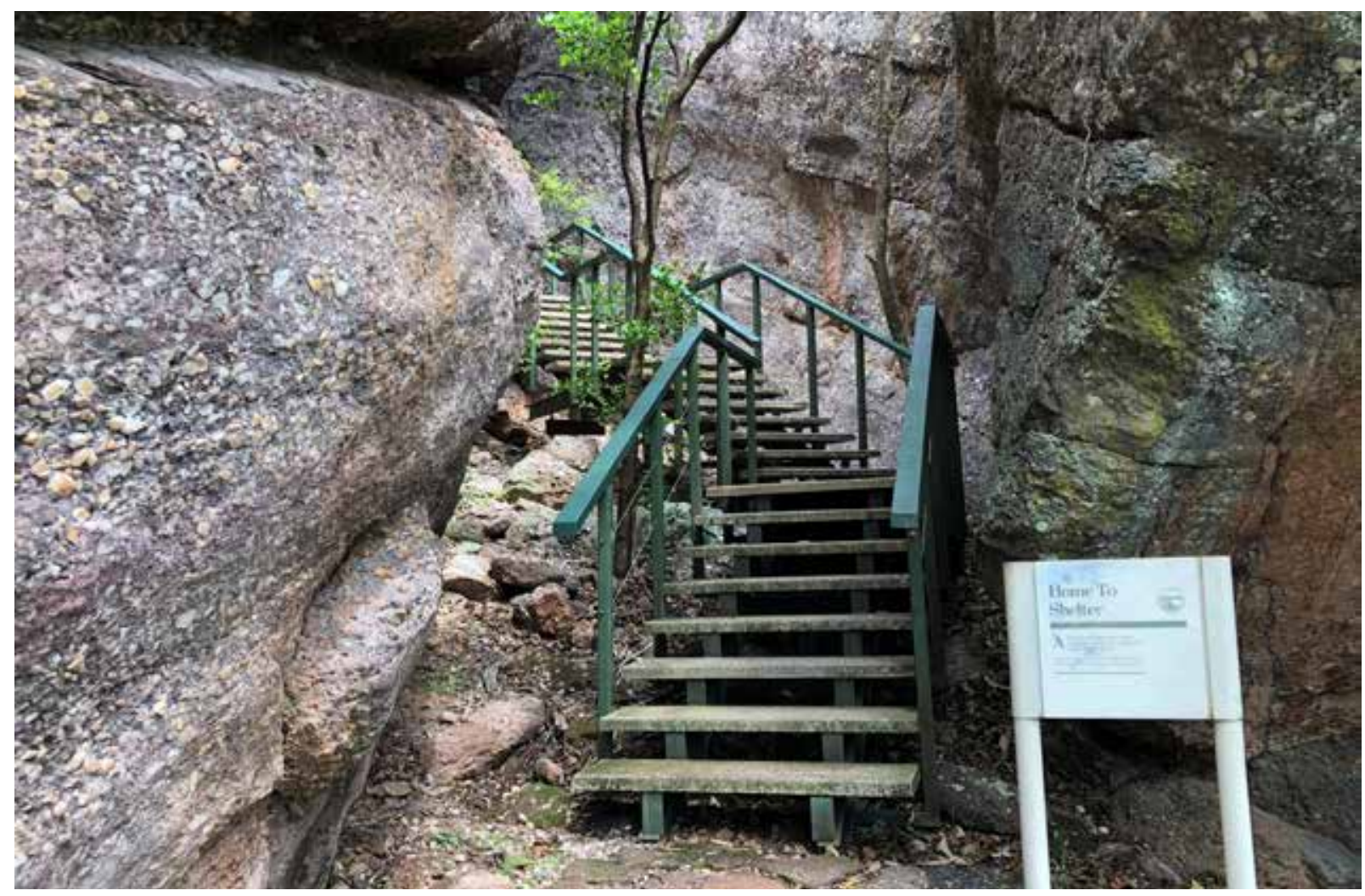




\section{Introduction}

There are multiple dimensions to concepts of heritage shaped amongst political, economic, cultural and geographic factors that influence the type of relationships to emerge in and between people, things and places. As a field of practice, heritage is entwined in policies that work across institutional frameworks and in temporally situated relationships embodied in in-place relations with people. In this regard, heritage has both a situated and transient presence. That is, it is generated through dialogue amongst individuals, and communities, and in becoming a subject of a governance system, both informs and authorises an ongoing, or alternate legacy.

The legal realm in which the protection of heritage occurs is embedded within shared, often implicit, concepts of common benefit through conservation as a practice that sustains and makes accessible elements of the past, for present and imaginings of generations into the future (MacLaren, 2006). However, there are limitations in a regulatory approach that instils care in a policy environment. The circumstance creates the added effect of conceptually removing a heritage place from a natural and cultural setting, into a bureaucratic system, that is often contested and contestable in different ways than are possible 'in-place' (Carman, 2000, p. 305). Cosmopolitics, therefore, suits purpose in this study as an analysis of the composition of a situated heritage narrative that places 'indigenous and other cosmologies together and separately in a particular time and place' (Verran, 2018, p. 112). The method also observes heritage in practice as a form of cosmopolitics that nurtures 'a collective ethos' in working dynamically between different knowledge systems that enact consensus and dissensus differently (Verran, 2018, p.112).

This study fits within the genre of Heritage Studies that as a developing interdisciplinary field examines the diversity of practices in which a collective of heritage is nominated and selected for protection, use and management. The research area has drawn scholars with interests in developing an understanding of heritage in its diversity of phenomenon as 'social actions' (Byrne, 2008); as a human right (Logan, 2012); as 'cultural processes' (Smith, 2006); or as 'things, sites and practices invested with value and sentiment, and claimed in collective ownership or guardianship to affirm continuity, authenticity and identity' (Filippucci, 2009, p.320).

In my study, I have adopted an ethnographic approach in the visualisation and mapping of heritage encounters at case sites selected across Northern Australia as a way to learn how meanings about heritage are represented on-site. This method is used as a way of charting the realities of heritage practices at a local level, consistent with the integration of global and national heritage initiatives. These encounters bring focus to heritage situations that emerge between cosmologies and enable an Australian STS way 'of exploring the enactment of, and the interactions between different realities' (Law, 2004, p. 122) that Verran describes as working 'separately and together' (Verran, 2018, p. 112).

\section{Charting Present Realities}

Kakadu National Park (Park) is the largest terrestrial National Park in Australia, extending across a wet/dry tropical landscape measuring 19,810 square kilometres (Kakadu National Park Board of Management, 2016). The Park has operated as a Commonwealth reserve since 1979 and in 1981 became Australia's first World Heritage site. The Park identifies as a Living Cultural Landscape in a dynamic reference to continuing Aboriginal traditions. Over $50 \%$ of lands 
within the Park limits are titled to Aboriginal peoples collectively named as Bininj/Mungguy. This grouped collective includes northern and southern clan groups that retain custodial obligations towards caring for country through customary laws that are a feature of strategic operations employed by Park managers (Kakadu National Park Board of Management, 2016). The term caring for country is broadly applied in park logics drawn from an entanglement of relations between people and place, in locations of customary estates, and in activities that integrate Aboriginal 'ecological knowledge' with science and conservation management practices (Davies et al., 2013, p. 13). The two-way model applied in joint management of Kakadu National Park, exists as a hybrid and dynamic form of management, ongoingly arbitrated as a consensus between Western and Aboriginal knowledge systems, aligned between policy and governance frameworks.

The Arnhem Land sandstone plateau is a dominant landform that extends 120 kilometres across the Park, connecting with low lying habitats (Needham, 1992, p. 34). The plateau provides a rugged platform adaptively used by Bininj/Mungguy and holds continuing evidence of art forms and living practices within the rock shelters, paintings and engravings, dispersed throughout the area colloquially known as stone country (Chaloupka, 1993). Recent archaeological excavation of a rock shelter at the settlement of Madjedbebe (belonging to the Mirror clan estate), in the vicinity but beyond the limit of the Park proper, has revealed evidence of Aboriginal settlement from $65 \mathrm{ka}$ setting the 'minimum age for the human colonisation of Australia' (Clarkson et al., 2017, p. 309).

In this paper, a recent field encounter at Kakadu National Park provides an analogous reference to Aboriginal Australian and Western cosmologies that intersect through the communication of meanings, in and about heritage places highlighted for visitor access within the Park. This study encounters differences in the expression of heritage realities and examines Park logics that work collaboratively to mainstream cosmologies as a dispersal of meaning that translate previous uses of the site. The analogy of 'home and shelter' is applied as a way to express the dualities that co-exist between the operability of Western and Aboriginal knowledge systems at places privileged for public access, and provisioned for heritage protection through national legislation, global conventions and Park management rationales.

\section{An Encounter - 'Home and Shelter’}

At the base of a stairway leading upwards to a rock shelter made accessible for public viewing within Kakadu National Park is a signboard titled 'Home to Shelter,' and it provokes enquiry into the play of words associated with the use of both terms. Specifically, is the concept of home and shelter one and the same for Aboriginal people? Does one invoke a sense of the other? Is a 'shelter' also a 'home' in an Aboriginal understanding of the world? Or is a Western doctrine being implied through the insertion of 'home' as a choice of words? Either way, use of these terms provokes thinking about ways to perceive the difference and sameness about a 'home' and a 'shelter' in attempt to understand concepts - implied or real - across both realms of Western and Aboriginal ontologies at this location.

This rock shelter, known as Angbangbang, sits nestled between massive quartz-sandstone conglomerate boulders that fell from the cliff face higher up on the escarpment following the erosion of softer rocks beneath (Needham, 1992). A large slab tilting at an angle of $30^{\circ}$ from the horizontal (Needham, 1992) is supported by adjacent boulders at either side forming a roofed enclave, shaded and protected from the elements. Towards the base of the rock face, 
at the back of the shelter, several sections are painted with line drawing and infilled patterns onto rough pebbled surfaces that remain discoloured from accumulated chemical deposits. The shelter and the painted surfaces remain susceptible to ongoing threats from 'growth of minerals salts on rock surfaces', and from 'ant trails, hornet's nests and physical flaking off of pigment' (Needham, 1992, p. 8).

Built infrastructure eases visitor access to the shelter. The stairway that climbs between a narrowing gap in opposing conglomerate boulders reaches a landing that extends to form a raised viewing platform above the floor of the rock shelter. Bench seating is provided for visitors that arrive via the stairway, or via an alternate route that enters the enclosure from the opposite side of the shelter. The stairway and raised platform are essential features that serve a dual purpose in protecting the site as well as enabling visitor access. However, they also generate a partition between built and natural forms within the shelter.

The built structure creates an artificial assemblage that imposes on the natural form of the shelter. The shaped presence modulates a Western perspective about the function, purpose and use of this shelter in a posed narrative not always synchronised with an Aboriginal reality associated with the same place. There are instances to support this view. The interpretation onsite generates a scene more attuned to a pattern of urban domesticity through its description of 'fire-lighting', 'gaining shelter', 'cake-making', 'story-telling' and 'rock painting'. ${ }^{1}$ The signage includes other references to activities routinely associated with Aboriginal livelihoods such as 'hunting tools being repaired'. The difficulty is that the simplification of the narrative privileges the familiar normality of contemporary Western patterns attuned to situated permanent homesteads. In this way, the interpretation diminishes the complexity of Aboriginal life and cosmology and its communal routines centred upon adaptation to seasonal environments. $A$ comment documented from the eminent (Australian-Austrian) architect Harry Seidler during 'a memorable visit to a rock shelter at Kakadu National Park' (date not provided) helps to untangle the moderation of the Western perspective experienced during this visit. Seidler is quoted during his visit to say 'Now this is architecture. These guys knew what they were talking about. Leaves us for dead' (quoted in Meinecke, 2006). The issue here is that while the comment generates enthusiasm about the setting, the form is natural, not built. Ignoring the adaptive use made of this shelter implies that such excellence in form is only achieved through built Western conventions, rather than executed through Aboriginal skills in adaptive use of existing forms.

Archaeological evidence from research conducted in the area is expressed to privilege Western conventions in other ways. The Arnhem Land plateau (and western Arnhem Land in particular), has received much attention from archaeologists. To date, 'fifteen rock shelter excavations have been published' between 1989 and 2017 (Wesley, Litster, Moffat, \& O'Connor, 2018, p. 6). Excavation includes the earthen floors of Angbangbang shelter during the 1980s by Dr Rhys Jones that produced organic deposits and material evidence in the form of stones tools and implements (Opitz, 2008). However, two more recent excavation reports (Wesley et al., 2018; May et al., 2017) of other rock art shelters on the plateau and related studies, together with results published in popular literature bring attention to inconsistent attribution of Aboriginal provenance in association with history and use of rock shelters, such as that at Angbangbang. These circumstances include under-reporting of evidence for structural features built within rock shelters that enhance their use, and provide protection from the elements (Wesley et al., 2018), a determined emphasis on securing date ranges to reconcile the earliest sequencing of

1 Quoted from Parks interpretation text at this location in December 2018 
occupation without similar interests in ethnographic and anthropological evidence based from traditional and cultural knowledge (May et al., 2017, p. 93), and inconsistency within public literature when reporting on the diaspora in which Aboriginal history begins in Australia (from about 60,000 years; Clarkson et al., 2017); that becomes variously described as new evidence for human activity within the global story of human evolution, without explicitly naming it as evidence for a continuing Aboriginal culture.

On the point of understanding an alternate perspective on the Western concept of 'home' Rhys Jones (Welsh-Australian archaeologist) describes a response by Frank Gurrumanamana, a traditional member of the Gidjengali Clan in Arnhem Land, on a visit with him to Canberra and its countryside.

Here was a land empty of religious affiliation; there were not wells, no names of totemic ancestors, no immutable links between land, people and the rest of the natural and supernatural worlds... Viewed from this perspective, the Canberra of the geometric streets, and the paddocks of the six wire fences were places not of domesticated order, rather a wilderness of primordial chaos. (Jones, 1985, p. 207)

In between these opinions, arise different perspectives that are not easily navigated within site encounters at Kakadu National Park without attention to the intersections and transections that both occur through a collaborative meaning-making process that respectfully acknowledges a multi-world cosmology.

\section{Making Analytic Meaning with this On-site Meaning Making}

How might we understand the limitations and juxtaposition of narrative at this encounter that moves to express realities of meaning-making processes as they occur in a fixed park location? In this, Verran offers cosmopolitics as a form of analysis that enables a way to see 'difference as difference' rather than as a reveal of a universal logic of the 'sameness of humanity' that inadvertently privileges a one-way consensus on seeing and believing reality (Verran, 2018). Furthermore, heritage practices and cosmopolitics share a common form as agents that 'are collective, partial, emergent and contingent' (Verran, 2018, p. 128) and carry an ethos that tolerates the 'uncertainties and specificities....about the nature of the real and how to intervene in it' (Law, 2004, p. 131). As an agent, heritage facilitates knowing different knowledge systems and perspectives that enter into policy deliberations, and cosmopolitics enables analysis of different groups working together with an expectation for continuation without consensus as a necessary surrogate. Within this frame of reference, the site encounters deliver a way to explore the mediation of a continuing relationship with heritage in the locale, rationalised in a translation of paradigms of difference and unrealised indifference, across the agency of heritage. The example drawn from one site encounter brings attention to the tensions that arise between logics that deliver meaning in and about places of heritage significance that result in unrealised differences, and in opportune moments for resolution of difference (Verran, 2018).

\section{Mediating heritage}

At a site management level, heritage conservation includes multiple stakeholders that are involved with planning and routines of Park management, and in delivery of visitor engagement programs. Within this linked network of activities and participants, a binary process of 
selection and exclusion reveals a meaning-making process in which heritage narratives are assembled, re-assembled or re-ordered. Such re-assembling methods are challenged by limitations of systems and resources that test the boundaries of capacity to implement change even on an occasion of consensus that predicts the necessity and desirability for change. In this sense, caring for heritage has an ephemeral quality, that is neither pre-defined nor programmed and is susceptible to circumstances that are localised and specific to each place somewhat regardless of the policy environment that delegates the legislative authority. Tironi and Rodrígues-Giralt describe concepts of care that bear relations to these scenarios of heritage as 'an ethico-political set of practices and circumstances and potentialities always concerning specific individuals facing specific problems in specific circumstances' (Tironi \& Rodríguez-Giralt, 2017, p. 89) Nor are the 'structured and structuring' (Dixon, 2004, p. 41) ways of meaning-making that occur at a local level isolated from other frames of reference. These intersect from numerous disciplines, other projects, and complex relations to reify the production of local knowledge and make visible realities in ways of knowing at each heritage locale through dialogue, engagement and interpretation. These processes articulate not only how heritage care is mobilised but also how narratives materialise.

\section{Conclusion}

The site encounter described as 'home and shelter' creates multiple forms of reality crafted through academic disciplines, Aboriginal voice, public literature and the moderation of visitor access. In this instance, the analysis arrives at a point of multiple and fractional realities (Law, 2004, p. 140) in which cosmopolitics activates a 'dissensus' (Verran, 2018, p. 128) in opinion about form and function, about materialities, a past and an Aboriginal ever-present. The disconnect between home and shelter remains unresolved as an enactment that is neither coherent or non-coherent which 'nevertheless resonate or interfere with one another to keep each other in place' (Law, 2004, p. 131). In this sense, heritage is mediated through the commonality of living needs and practices to make only tenuous links to the lived and living realities embodied in the cultural landscapes of Kakadu National Park. Nor does the interpretation extend possibilities for a Western understanding of an Aboriginal existence as the moderation remains limited by a Western perspective of a singular reality. As such, the site encounter described in this paper shows that there are better and worse ways to interpret heritage in-place at Kakadu National Park. The challenge remains in the ways that meaningmaking processes are enabled between diverse world cosmologies and harnessed to maintain knowledge production, shown here as an example within the complexity of a lived and living landscape.

\section{References}

Byrne, D. R. (2008). Heritage as social action. In In G. Fairclough, R. Harrison, J.H. Jameson, \& J. Schofield (Eds), The Heritage Reader (pp. 149-173). London: Routledge.

Carman, J. (2000). ?Theorising a Realm of Practice?: introducing archaeological heritage management as a research field. International Journal of Heritage Studies, 6(4), 303-308. doi:10.1080/13527250020017726

Chaloupka, G. (1993). Journey in Time. Melbourne, Australia: Reed International Books.

Clarkson, C., Jacobs, Z., Marwick, B., Fullagar, R., Wallis, L., Smith, M., . . Pardoe, C. (2017). Human occupation of northern Australia by 65,000 years ago. Nature, 547, 306-310. doi:10.1038/nature22968 
Davies, J., Hill, R., Walsh, F. J., Sandford, M., Smyth, D., \& Holmes, M. C. (2013). Innovation in Management Plans for Community Conserved Areas: Experiences from Australian Indigenous Protected Areas. Ecology and Society, 18(2). doi.org/10.5751/ES-05404-180214

Dixon, R. (2004). Boundary Work: Australian Literary Studies in the Field of Knowledge Production. Journal of the Association of Australian Literature Studies(3), 27- 43.

Filippucci, P. (2009). Heritage and methodology: a view from social anthropology. In M. L. Stig Sorensen \& J. Carman (Eds.), Heritage Studies - Methods and Approaches (pp. 319-325). London: Routledge.

Jones, R. (1985). Ordering the Landscape. In I. Donaldson \& T. Donaldson (Eds.), Seeing the First Australians (pp. 180-209). Sydney: Allen and Unwin Pty Ltd.

Kakadu National Park Board of Management. (2016). Kakadu National Park Management Plan 2016-2026. Canberra: Australian Government Retrieved from www.environment.gov.au/topics/national-parks/ parks-australia/publications.

Law, J. (2004). After Method - Mess in social science research. London: Routledge.

Logan, W. (2012). Cultural diversity, cultural heritage and human rights: towards heritage management as human rights-based cultural practice. International Journal of Heritage Studies, 18(3), 231-244. doi:10.1080/13527258.2011.637573

MacLaren, A. N. (2006). Protecting the past for the public good: archaeology and Australian heritage law. (Doctor of Philosophy), University of Sydney, Sydney. Retrieved from http://hdl.handle.net/2123/1602

May, S. K., Taçon, P. S. C., Wright, D., Marshall, M., Goldhahn, J., \& Sanz, I. D. (2017). The rock art of Madjedbebe (Malakunanja II) In D. Bruno, P. Taçon, J.-J. Delannoy, \& J.-M. Geneste (Eds.), The Archaeology of Rock Art in Western Arnhem Land, Australia (Vol. 47, pp. 87-108). Canberra: ANU Press

Meinecke, D. (2006). Obituary - vale Harry Seidler 1923-2006. Architecture Australia. May 2006. Retrieved from https://architectureau.com/articles/obituary-14/

Needham, R. S. (1992). Geology of the walking trails in Kakadu National Park. (\#4). Canberra: Commonwealth of Australia Retrieved from https://d28rz98at9flks.cloudfront.net/14605/Rec1992_081.pdf.

Opitz, J. (2008). The interpretation of Australian heritage sites : Kakadu and Port Arthur (Doctor of Philosophy), Charles Darwin University, Retrieved from http://espace.cdu.edu.au/view/cdu:8302

Smith, L. (2006). Uses of heritage. New York: Routledge.

Tironi, M., \& Rodríguez-Giralt, I. (2017). Healing, knowing, enduring: Care and politics in damaged worlds. The Sociological Review Monographs, 65(2), 89-109. doi:10.1177/0081176917712874

Verran, H. (2018). The Politics of working cosmologies together while keeping them seperate. In M. de la Cadena \& M. Blaser (Eds.), A World of Many Worlds (pp. 112-130). Durham, NC: Duke University Press.

Wesley, D., Litster, M., Moffat, I., \& O'Connor, S. (2018). Indigenous built structures and anthropogenic impacts on the stratigraphy of Northern Australian rockshelters: insights from Malarrak 1, north western Arnhem Land. Australian Archaeology, 84(1), 3-18. doi:org/10.1080/03122417.2018.1436238 